\title{
Science and Challenges for Cuban Public Health in the 21st Century
}

\author{
Agustín Lage MD PhD
}

\begin{abstract}
Cuba's public health outcomes are rooted in political and social phenomena that have favored achievement of health indicators well above expectations for an economy of its size. A less studied causal component of Cuba's development in health is the creation, from early in the 1960s, of scientific research capacity throughout the health system, including use of science to launch a domestic industry for manufacturing high-tech products. This component should play an even greater role in meeting Cuba's 21st century health challenges, especially the demographic and epidemiological transitions, increasing prevalence of chronic diseases, rapid emergence of a complex-product biotechnology pharmacopoeia, greater molecular stratification of diseases, rising health costs, and the need to maintain communicable diseases under control in a global context of climate change and more population mobility.

Tackling these challenges will demand greater scientific influence in the health system, application of a scientific approach in all activities and at all levels, and integration with scientific endeavors of other sectors such as agriculture, industry and education.
\end{abstract}

KEYWORDS Public health, science, health care costs, health workforce, chronic disease, biotechnology, immunology, aging, Cuba

\section{INTRODUCTION}

Although public health is a complex, multifactorial phenomenon requiring qualitative evaluation that cannot be reduced to a series of statistics, some of its aggregate indicators are universally accepted as expressions of the quality and impact of health interventions. Life expectancy at birth and mortality are two of these emblematic indicators.

Public health outcomes in Cuba since the 1959 revolution are recognized worldwide, supported by sound data. Life expectancy at birth is over 79 years - 7 years longer than the world average and 3 years more than in Latin America.[1] Infant mortality in 2017 was 4 per 1000 live births, the lowest in the country's history and lower than the US rate. Cuba's physician-population ratio $(81.9 / 10,000)$ is one of the highest in the world. The country has eliminated 14 infectious diseases, and 9 others are no longer public health problems, as their rates are under 0.1 per 100,000 population.[1] In 2010, Save the Children rated Cuba the best country in Latin America in which to be a mother.[2] Cuba has one of the lowest HIV infection rates in Latin America $(0.4 \%$ of the population aged 15-24),[3] and in 2015 was certified by WHO as the first country to eliminate mother-to-child transmission of HIV and syphilis.[4] The Bloomberg Report of February 2019 ranked

IMPORTANCE This article highlights the little-explored phenomenon of the early introduction, following the 1959 revolution, of a science-based approach to knowledge construction, inherent in the strategies leading to Cuba's public health achievements.
Cuba 30th among the healthiest countries in the world-higher than all Latin American countries and the USA.[5] The list of such hard facts and indicators could be much longer.

Cuba's results offer an encouraging exception to the usual correlation between health indicators and size of GDP. In this regard, two interrelated characteristics of trends in Cuban health indicators deserve special mention. The first is that changes in the health picture happened rapidly. Life expectancy at birth in 1960 was estimated at 63 and the country had less than one tenth of the physicians it has today.[6] Infant mortality prior to 1960 is hard to determine due to incomplete data, but is estimated at 34.8 per 1000 live births, almost ten times the current rate.[7] The second characteristic worth noting is that not only were the changes rapid, but they preceded economic growth, meaning that they were achieved with limited material resources and in a context of external economic hostility and even aggression.[8-10]

After 1990, this dissociation became evident once again in a longitudinal analysis derived from an "undesirable experiment," when the Cuban economy contracted by $35 \%$ upon the loss of its advantageous economic relations with the European socialist countries and the tightening of the economic embargo imposed by the US government-an era known in Cuba as the "special period."[8-10] Conventional wisdom and models describing the association between economics and health[11] predicted that Cuba's health indicators would deteriorate (as they did in Russia and Eastern European countries). However, they did not decline to the degree anticipated.[12] Infant mortality, for example, continued to improve during the 1990s, despite a GDP that did not return to its 1989 level until 2003, a trend that continued through the next decade (Figure 1).

Later in the current century, Cuba's positive deviation from the association between material wealth and health indicators has become evident once again in a cross-sectional analysis by country of the relation between GDP and these indicators. The point corresponding to Cuba in these figures deviates from the line of best fit between GDP and life expectancy and shows that life expectancy is five years longer than would be expected, given the size of the economy. Something similar happens with infant mortality, which also deviates positively from predictions based on economic indicators.[11]

This counterintuitive phenomenon (in which wealth and health are not bound together) in post-1959 Cuban public health merits deeper study, as it can provide insights for other countries as they develop strategies to achieve universal health.

\section{Roots of the paradox}

The main explanations for Cuba's health outcomes are political in nature.[4,13] These are reflected in principles resulting in: the priority that Cuban socialism has always given to public health; the single, free and universal character of the health system; an economic order that provided the state with resources for health programs; the capacity for mobilization of human resources; and the social cohesion developed around these policies. As a result, 
Figure 1: GDP and infant mortality trends in Cuba

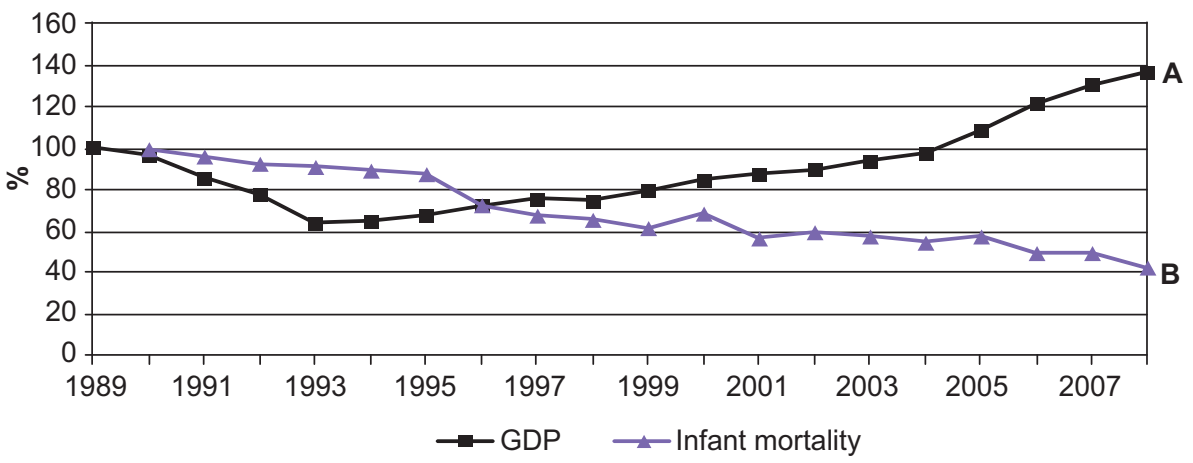

Source: Secondary data, GAPMINDER[11]

A: 1989 GDP, in constant dollars B: \% of 1990 rate per 1000 live births (10.7 in 1990; 4.7 in 2008)

GDP: gross domestic product

health promotion and disease prevention, a robust primary care strategy and human resource training have become the cornerstones of Cuban public health.

In this context, it is noteworthy that Cuba's scientific approach to public health policies and programs, coupled with an emphasis on knowledge construction, have played an important causal role in the country's health achievements and will continue to do so. They also help explain why the health status of the Cuban population has advanced beyond predictions based on economic indicators alone.

Human health is not a simple biological attribute. Both the classic definition adopted by WHO in its constitution of 1946 (Health is a state of complete physical, mental, and social well-being and not merely the absence of disease or infirmity)[14] and other more recent documents that object to the concept of "complete wellbeing" $[15,16]$ point to other factors that shape health throughout the life course.

Since the 1970s, and from different points along the ideological spectrum, the scientific literature reflects growing recognition of health's social determinants.[17,18] In fact, WHO recognizes that most of the global burden of disease and the principal causes of health inequities found in all countries stem from the conditions in which people are born, live, work and age. These social determinants of health represent a shift in focus that encompasses not only determinants that are social per se but also economic, political, cultural and environmental.[19]

The obvious corollary of this definition is that if there are social determinants of the burden of disease and death, there also must be social determinants of improvement in health indicators. Worthy of mention in this regard are Cuba's organized social response since the 1960s and the country's capacity to resist despite economic pressures, particularly those stemming from the US embargo imposed since 1962.[20]

A related factor explaining Cuba's early health improvements was the simultaneous attention, development and priority accorded to health and education-the latter considered an important social determinant of health. Health programs began in 1960 with the creation of the Rural Social Medical Service, while educational programs began in 1961 with the National Literacy Campaign. These two arenas of social endeavor were mutually reinforcing, an example of the close structural correlation between health and education.[21]
Thus, social policies that prioritized both universal public health system development and attention to social determinants contributed to improved health outcomes in Cuba, as did a third, less-studied component of Cuba's health strategy, the subject of this paper: its scientific approach closely connected to the processes of knowledge construction.

\section{SCIENCE'S ROLE IN PUBLIC HEALTH}

Superficially, science tends to be identified with laboratories full of complicated instruments, but this is not its essence. Science is primarily a way of thinking, a structured method for obtaining and creating new, generalizable and objectively verifiable knowledge.[22]
The ability to make verifiable predictions and the refutability of hypotheses are the hallmarks of scientific thinking. Its tools are objective measurement of phenomena, identification of associations between data and evaluation of interventions.

This definition is independent of the complexity of the instruments used. These may be simple (e.g., a survey), or very complicated and expensive (e.g., a DNA sequencer or positron emission tomography scanner), depending on the problem studied. The essential thing is not the data collection instrument, but rather the capacity to discern what data should be collected and how to interpret them.

The scientific method is a cultural triumph of the 18th century Enlightenment in Europe. Born of physics, it spread rapidly to the biological sciences and medicine, and more recently, with particular characteristics, to the social sciences. In medicine, it gave rise to "evidence-based medicine" and clinical research methodology. In population health, it gave rise to the epidemiological method and scientific assessment of the impact of collective health interventions.[22]

Public health practice is at once a series of specific actions to improve health and also a continuous process of knowledge construction and dissemination. Knowledge dissemination by itself can alter health indicators through a complex process of mediating variables, among which higher risk perception, a greater culture of health, and conscious lifestyle changes play a key role. Also of interest to science are the ways knowledge is disseminated, incorporated into the thinking of its intended public and subsequently transformed into behavioral and lifestyle changes.

Production of scientific knowledge rapidly accelerated in the 20th century, with two momentous consequences for public health. The first is that the time it takes knowledge and medical technologies to become obsolete became shorter than the working life of a health professional.

While 19th century physicians could practice for 40 years using what they had learned in medical school, today's physicians must update their arsenal of knowledge and technologies several times in their lifetime. Much of what they learned in medical school will probably be obsolete in less than 20 years. Thus, curriculum designers find it ever harder to predict what knowledge and skills students will need 20 years after graduation. And the assumption that education also means "teaching how to learn"-that is, 
to interpret and apply new scientific knowledge-becomes all the more central.

The second consequence is that new knowledge and technologies appear and are replaced before there is time to fully evaluate them. Thus, health professionals often will be working with a degree of uncertainty with emerging and inadequately vetted technologies. This means they must know how to distinguish between different levels of evidence supporting each new proposal and to participate themselves in validating the health technologies they use in their specific context.

Both phenomena require all health professionals to conduct scientific research and be proficient in its methods.

\section{SCIENCE IN CUBAN PUBLIC HEALTH'S \\ INSTITUTIONAL EVOLUTION}

Scientific development is a two-term equation. One of them, quantitative, is expressed in terms of the number of scientists, institutions and articles published; the other, conceptual and strategic, lies in the strength of the connections between science and other spheres of human endeavor-among them the promotion, preservation and improvement of health, and the prevention of disease.

Health programs in Cuba embraced these ideas in the early 1960s, just after the creation of the new Ministry of Public Health (MINSAP) in August 1961, replacing the former Ministry of Health and Social Assistance. By integrating medical care, teaching and scientific research into all health institutions, they have become centers for knowledge construction and dissemination, adding to their value as service providers.

Also dating from the 1960s is the Statistical Information System, which began by improving vital statistics. The 1960 s also saw the first programs for vaccination and infant mortality reduction incorporating a scientific design and objective evaluation criteria, as well as greater attention to epidemiology with the first national forum in this field held in 1963. In 1965, the National Scientific Research Center, including an important biomedicine division, was founded under the Ministry of Higher Education. Its scientific personnel were trained from the ranks of medical students (at the time, the majority of university students), particularly those enrolled in the Victoria de Girón Institute of Basic and Preclinical Sciences, created in Havana in 1962.[23]

In 1966, the first eight MINSAP research institutes were created (Oncology and Radiobiology, Cardiology and Cardiovascular Surgery, Gastroenterology, Hematology and Immunology, Angiology and Vascular Surgery, Neurology and Neurosurgery, Nephrology, and Endocrinology). These were followed by the establishment of the Institutes of Nutrition and Occupational Health. During this period, the Hygiene, Epidemiology and Microbiology Institute, created before 1959, reached full scientific and technical development, as did the newly baptized Pedro Kourí Tropical Medicine Institute, named after the scientist who founded it in 1937. This made a total of 12 institutes.[24] In 1973 came the founding of the Health Development Institute (IDS), which conducted major studies such as the Growth and Development Survey of the Cuban population.[25] These institutes, each in its own field, integrated basic research and technology assimilation, as well as epidemiological projects and those devoted to health systems and services evaluation.
For example, as early as 1981, the National Oncology and Radiobiology Institute housed the laboratories that produced the first monoclonal antibodies in Cuba; the original technology had been developed in 1975.[26] This institute was also the gateway for the technological assimilation of radiotherapy and nuclear medicine, including the first radiation protection service; it was the incubator for the first specialized clinical trials unit, the National Cancer Registry[27] and the initial versions of the National Program for Reduction of Cancer Mortality.[28] Each of these scientific institutions has a similar story. Science was part of virtually all actions at all levels that changed Cuba's health picture.

In summary: In 1959, Cuba had only one institution devoted to higher education in medicine-the University of Havana Medical School. By 2018, it had 25 medical faculties in 13 medical universities throughout the country. This human resource capacity has been supplemented today by 37 Science and Technological Innovation Units,[13] over 4300 researchers and more than 1000 PhDs in the national health system. Strengthening this community is Infomed, the system's national online platform for communication, knowledge sharing and knowledge creation, established in 1992 from the embryonic National and Provincial Medical Sciences Information Centers set up nearly two decades earlier.[29]

\section{CUBAN SCIENCE AND THE INDUSTRY OF HEALTH}

Biotechnology took off in the 1980s with the creation of the Biological Front (directly overseen by the highest level of government) and the launch of the Biological Research Center in 1981, the Genetic Engineering and Biotechnology Center in 1986, the Immunoassay Center in 1987, and the other institutions that by 1992 were included in the Western Havana Scientific Pole, with more than 10,000 employees.[30]

In 2012, these institutions merged with the enterprises of the pharmaceutical industry, and together gave rise to the umbrella company BioCubaFarma, which at this writing includes 34 enterprises, supplies the health system with more than 1000 products (including $62 \%$ of the essential medicines list), holds 182 patents, conducts over 100 simultaneous clinical trials with its products at 200 clinical sites, and exports to 49 countries.[31]

Behind these figures lie concepts. With the advent of biotechnology in Cuba arose the concept of the "research and production center," where scientific research, production and export activities take place under the same management in a closed financial loop,[30] the precursor of the high-tech socialist state enterprise. These institutions embody a trend that emerged in the industrial sectors of the more technologically developed world in the mid20th century, whereby scientific research became an integral part of the activities of corporations, which ipso facto, shouldered the burden of their financing. An original concept emerged in Cuba, however, that did not replicate the global biotechnology scheme: the integration of industry and health programs.[13,30]

Several examples illustrate this. The first major success of Cuba's nascent biotechnology sector was the meningococcal meningitis $B$ vaccine, the first achieved globally, which halted an epidemic of this disease in the 1980s. The Finlay Institute not only created the vaccine but was an active participant in confronting the epidemic. Later, the recombinant hepatitis $B$ vaccine brought the incidence of that disease down to zero in children under 15.[13,30] 
The Molecular Immunology Center achieved 100\% coverage of chronic kidney failure patients with recombinant erythropoietin and today plays a leading role in the country's cancer control program. Several of its projects (such as the one in Villa Clara Province for access by lung cancer patients to immunotherapy) are complex health interventions aimed at assessing the population impact of supplying advanced biotech products to all cancer patients in a given territory.

Possibly the most outstanding example of the synergy between cutting-edge technology and primary health care lies in the Immunoassay Center (CIE). This research and production institution was created in 1987, but its founding team had been working throughout the previous decade on immunoenzyme diagnostic techniques and computerized equipment to enable inexpensive implementation of these techniques on a massive scale. In its 30 years of operation, CIE has developed 26 diagnostic reagent kits for 19 diseases, as well as 15 types of diagnostic equipment and 25 software packages. It has 1562 laboratories in Cuba and 546 abroad.[32]

The most interesting aspect of CIE's experience is that virtually all its products have emerged as part of a public health program, and their integration into these programs has shaped product design. Thus, CIE products are part and parcel of programs such as maternal and child health; certification of blood, placenta and organs; epidemiological surveillance; cancer and diabetes control; and minimally invasive neurosurgery-all products used in the national health system.[13,30,32]

What often happens in countries with major pharmaceutical and biotechnology industries is that the industry's strategy (which seeks to maximize profits) and the health system's strategy (which seeks to maximize coverage and impact on population indicators) are at variance and often mutually exclusive.

In contrast, Cuba's biotechnology sector is already shaping an industry model that takes responsibility for its products' coverage and impact on population indicators, designs population health interventions and participates in their evaluation and financing. This strategy may drive up costs in the short term, but in the medium term, it reinforces the "proof of concept" of its products' impacts, and hence, its competitive position. The full cycle is completed by the twin means of exports and health impacts, mutually reinforcing.

\section{THE 21ST CENTURY BRINGS NEW CHALLENGES}

The Cuban health system has successfully responded to the challenges of the 20th century in which the main challenges were achieving full health service coverage, improving maternal and child health, and controlling infectious diseases. These challenges were tackled essentially with firm political will supported by parallel successes in education and the strong cohesion and public mobilization generated by Cuba's social project. The first point of this essay is to underscore the role of science in achieving these results. The second is that the role of science should be expanded further to meet the health challenges of the 21st century.

Disregarding the inevitable exhaustion of reserves to maintain it indefinitely, the past decade's trend toward stabilization of life expectancy (about 80 for women and 76 for men) and infant mortality (about 4 per 1000 live births)[1] suggests the emergence of new barriers to steady improvement in health benchmarks, the nature of which needs to be understood. Apart from climate change, the global effects of migration and the phenomenon of multidrug resistance, this article proposes to highlight five major challenges to health improvement, namely: (1) population aging; (2) non-communicable chronic diseases; (3) the biological pharmacopoeia and molecular stratification of diseases; (4) rising costs of medical services and drugs, and the distorting effects of the market; and (5) emerging and reemerging diseases.

Population aging The Cuban population has experienced a steady increase in life expectancy for years, coupled with a steady decline in birth rates, resulting in an aging population. The percentage of older adults (aged $\geq 60$ years) grew from $12.9 \%$ in 2000 to $20.1 \%$ in $2017 .[1]$

Population aging is not limited to the quantitative fact of longer life expectancy, which demands social actions to ensure health care in older age and adaptation of institutions and work processes; rather, it also involves a qualitative change in human biology, which has come about as a result of evolution, as people live decades in the postreproductive stage, while the human genome has been selected over the course of thousands of years to maintain homeostasis and species survival in the prereproductive stage.

One of the consequences of this disconnect between the genome and the current conditions of life is "inflamm-aging," a state of chronic, low-grade inflammation that accompanies aging, even in the absence of disease,[33,34] for which health systems currently have no defined strategies.

Non-communicable chronic diseases Accompanying population aging is an increase in non-communicable chronic diseases: atherosclerosis, hypertension, diabetes, cancer, arthritis, Alzheimer's disease and others, which also involve a qualitative change. Table 1 summarizes essential features that differentiate chronic diseases of adults from infectious diseases and
Table 1: Differences between acute and non-communicable chronic diseases

\begin{tabular}{|c|c|c|}
\hline Attribute & Acute & Chronic \\
\hline Conditions & Infections, injuries, poisoning, etc. & $\begin{array}{l}\text { Cardiovascular diseases, cancer, chronic } \\
\text { kidney disease, diabetes, degenerative } \\
\text { diseases of the central nervous system, } \\
\text { etc. }\end{array}$ \\
\hline Onset & Sudden & Insidious over time \\
\hline Causes & Single primary factor & Multiple \\
\hline Clinical progression & Generally rapid & Slow \\
\hline Treatment & Single targeted interventions & Multiple, complex interventions \\
\hline $\begin{array}{l}\text { Aim of medical } \\
\text { intervention }\end{array}$ & Health restoration & $\begin{array}{l}\text { Long-term control, treatment of } \\
\text { complications }\end{array}$ \\
\hline Life stage affected & Throughout life course & $\begin{array}{l}\text { Mainly postreproductive: relaxed } \\
\text { homeostatic controls, no protective } \\
\text { genes selected through evolution }\end{array}$ \\
\hline
\end{tabular}

Source: Author 
accidental injuries in terms of their onset, progression, causality, treatment aims, stage of life in which they appear and their underlying mechanisms.

Modern health systems emerged in many countries in the 20th century and evolved in an era in which the essential tasks, largely successful, were infectious disease control and improved maternal and child health. These systems were developed to address single primary causes, basically external, through targeted and public health interventions. However, the structure and functioning of those health systems are not well adapted to the era of chronic diseases. Reconfiguring them for this purpose will require research not only on new diagnostic and treatment products, but also on the workings of the health systems themselves, as well as social and intersectoral action to improve the quality of life of older adults and people with disabling chronic diseases.

Another important transformation required of health systems will be adaptation to the modern "life course" paradigm, which has broadened the temporal horizons of causality and included transgenerational effects. The causes of today's diseases do not lie solely or even mainly in exposure to risk factors in the immediate term, but in a complex pattern of contextual influences present throughout the life course, in prenatal life, and even in previous generations. The contribution of scientific research across its spectrum of specialties-from basic sciences to health administration, stretching from clinical to epidemiologic, public health, and the social sciences-has been and must be pivotal.[35]

The biological pharmacopoeia and molecular stratification of diseases New products will also be necessary. Many will derive from the so-called "biotechnology revolution," which is essentially the ability to identify and clone genes and re-express them in suitable vectors on an industrial scale. This revolution is still in its infancy. Its first significant product was recombinant human insulin, registered in the USA in 1982.[36] Before then, the vast majority of drugs were chemical products, but since then, the fraction of the pharmaceutical market corresponding to biological products has grown and currently stands at $25 \%$. The fact that today, more than 900 biotech products are in clinical trials and $40 \%$ of all drugs in the research pipeline are biological products leads to the prediction that these products will soon represent more than half the pharmaceutical market (Figure 2).[37] For example, current predictions indicate that by the 2020s, more than $60 \%$ of cancer patients will receive some form of immunotherapy.[38]

Biological pharmaceuticals will increase specificity of treatments. This good news, however, implies the challenge of identifying the molecular targets of each biopharmaceutical and the genes that predict the sensitivity to each treatment. Each known disease will likely be stratified into many subtypes and variants, each with a different treatment, in what is now known as "precision medicine." This will require physicians to interpret many biochemical and genetic data simultaneously to guide therapy decision-making.
The rising cost of medical services and drugs and the distorting effects of the market All these changes already have-and will continue to have-a substantial impact on the cost of medicines and medical services, threatening the collapse of health systems forced to shift from a chemical pharmacopoeia based on widely used, more affordable generic drugs to a biological pharmacopoeia consisting of expensive products targeting a small niche market of patients.

Part of this cost increase is due to technical components: more complex processes associated with production of biological substances, and wider molecular variability, adding to costs of quality control systems. At some point, though, technology development is expected to lower the cost of these processes.

But another cost component is derived from the distorting effects of the market. Pharmaceutical research funding changed in the second half of the 20th century. As late as the 1970s, less than $5 \%$ of clinical trials were funded by private industry. In 2004 , that percentage was already $57 \%$; today it is higher.[39]

This change puts scientific decision-making in the hands of industry, which in turn is subordinate to market interests in most contexts. The result is the search for small, incremental improvements to reduce the risk of clinical trials, making for only minor differences in previous treatments that are nevertheless sufficient to patent and sell at a higher price. This, in turn, finances aggressive marketing to ensure that new products are financed by health systems. This is not a technical but a political component and has been explored elsewhere.[40,41]

The arrival of many biotech products also has implications for science's impact on health systems, since it will require deployment of national productive capacity, as well as capacity to assess population impact of each potential new technology. Some countries have created institutions specifically to conduct cost-benefit analyses.[42]

The problems described in the preceding paragraphs have increased hand in hand with the rising incidence of noncommunicable chronic diseases.

Figure 2: World market share of conventional and biotechnology pharmaceuticals

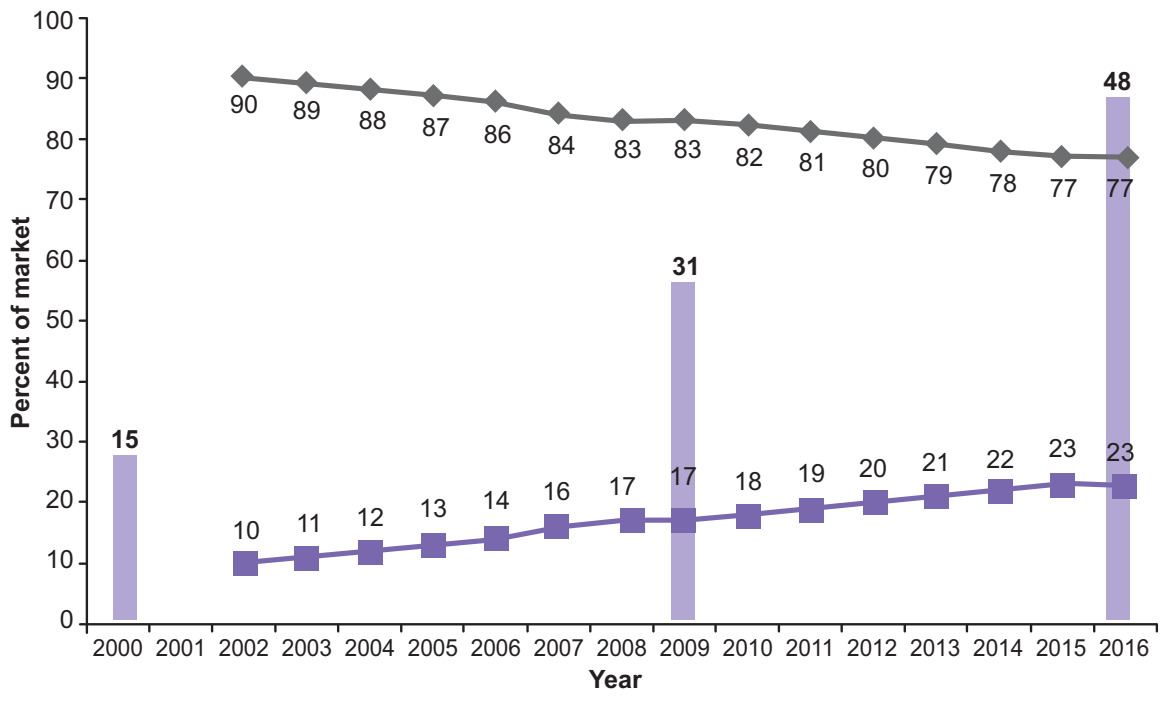

- Conventional/Unclassified

Biotechnology

Biotech share of 100 top-selling drugs

Source: Lage[40] with data from Evaluate Pharma,[37] used with permission 
Emerging and reemerging diseases Infectious diseases have not disappeared; there are new ones and some that had disappeared are reappearing. This phenomenon not only has biological, but socioeconomic and political components. Suffice it to mention, for example, the antivaccination movement, which is growing even in the middle and upper classes of wealthy countries, posing a serious threat to public health and constituting a retreat to eras of underdevelopment that the world believed it had definitively left behind.[43]

Climate change, growing urbanization and population mobility are creating the conditions for this reemergence of infectious diseases, which now is occurring in aging populations.

\section{THE RESPONSE AND ITS DEMAND FOR KNOWLEDGE CONSTRUCTION}

The first message of this article is that while the political will, priority and role of the state (and not the market) in health, interdisciplinarity and social cohesion are at the root of post-1959 Cuban public health outcomes, less studied but also important has been the role of an early focus on scientific methodology and research practice.

Measuring phenomena, describing associations and objectively evaluating interventions are the three basic functions of health research promoted since the founding years of Cuban public health. Added to this was the role of science in building an industrial sector for biotechnology and the pharmaceutical industry, supporting the effort with a scientific approach to technology evaluation and adoption, and the capacity to generate innovative products.[22,30]

The second message is that the role of science in health must be expanded in the immediate future, included in all stages of knowledge construction from basic research to health care delivery (also with a scientific approach), and encompassing development of products and production processes.

History teaches us that decades may pass before a scientific discovery (even a well-validated one) has an impact on population health. By way of example, the smallpox vaccine was discovered in 1798, but it took almost 200 years (until 1980) to eradicate the disease.[44] Although the polio vaccine was developed in 1955, wild-strain cases are still being reported.[45] These intervals could be reduced through a scientific approach to research on barriers to application of advances and on health intervention implementation processes that takes into account factors such as patient, family and community education-all vital as well to the muchneeded shift from the concept of preserving health to that of constructing health.

In the face of a health situation marked by a growing predominance of non-communicable chronic diseases, significant impacts are unlikely to be obtained with straightforward measures as occurred with vaccines to combat infectious diseases. More than discrete measures, the greater need will be for policies and programs designed to consider context and its influences on individual and population health at multiple levels over extended periods, with special emphasis on critical points in the life course.[35] Introducing new products and technologies proposed by scientists into the health system will be more complicated and multifactorial, and their evaluation more complex.
The first step in preparing our science system to tackle the challenges of the 21 st century will be to explicitly develop and modernize a "demand for knowledge." What knowledge, skills and technologies do we need for this new stage, given our material conditions?

- We will have an older population, demanding more scientific research specifically targeting this stage of life. We will have a disease landscape in which non-communicable chronic conditions will play a key role and for which control strategies must address biological problems not yet solved by science, as well as complex interventions targeting both the individual and other critical actors (family, community, school and workplace).

- The system's center of gravity will increasingly shift towards the primary care level, where more scientific research must be directed. Institutions must also be strengthened to permit greater scientific activity at this level.

- A more intersectoral approach in health programs and scientific research will demand greater participation by professionals outside the health system (for example, in nonmedical universities). It will be especially important to improve communication between the health and social sciences as attention migrates from the study of disease to the study of risk, and from there, to positive health indicators; and from the concept of "preserving health" to "constructing health," which considers people not as passive beneficiaries of services but instead as active agents in the health-building process.

- In the global context created by market-driven industry, replete with costly medicines and equipment whose health impacts are not always sufficiently validated, substantial scientific capacity will be needed to decide what new items to assimilate and also how to continue developing our own industries.

Although high-priority, centrally directed scientific projects will continue to be necessary, the scientific challenges of the 21st century call for a response distributed across the system, where all professionals involved in health are proficient in scientific methodology (regardless of the complexity of the equipment they can access in each location) and embrace a culture in which they measure and evaluate what they do. It will be increasingly necessary to have a health system armed with a scientific culture expressed in day-to-day decision-making, which implies data-driven reasoning, alternatives designed based on verifiable hypotheses, decisions submitted to impartial critique, impact assessment. This also means rejection of improvisation, pseudoscience (which, like infections, often reemerges), uncritical imitation and superficiality.

All of this is possible. It will be necessary to overcome the economic constraints faced by all health systems, exacerbated in Cuba by the US economic and trade embargo that persists and is reinforced despite its overwhelming worldwide moral rejection.

Nevertheless, there are favorable conditions:

- Human capital, since Cuba has one of the highest densities of health professionals in the world, armed with knowledge and values;

- Universal coverage and access to the services of a single and public health system and the strength of its primary care; 
- A national industry that is not in private hands, with capacity to assimilate cutting-edge technology and generate innovative products;

- A medical sciences university system covering all provinces and actively participating in scientific research;

- An educated, well-informed and engaged population, especially in health-related activities;

- Intersectoralism and political will, key premises determining the health of the Cuban population;

- Half a century of experience in health development, including constructing knowledge in the biological, clinical, epidemiological and operational spheres.
How far we advance in public health in the 21st century will depend on intelligently leveraging these conditions, and on the volume and quality of messages drawing on the Cuban experience that we can communicate to the international health community.

\section{CONCLUSIONS}

Scientific research has been an important component of Cuban health achievements and must serve as a basic resource for tackling current challenges and those already visible on the horizon. This endeavor does not exclude any sector of society or branch of science and relies on the basic synergy among science, education and development, a distinctive Cuban hallmark in the field of health. -1 .

\section{REFERENCES}

1. National Health Statistics and Medical Records Division (CU). Anuario Estadístico de Salud 2017 [Internet]. Havana: Ministry of Public Health (CU); 2018 [cited 2019 Feb 16]. 206 p. Available from: http://files.sld.cu/dne/files/2018/04/Anuario -Electronico-Espa\%C3\%B1ol-2017-ed-2018. pdf. Spanish.

2. Save the Children. Women on the Front Lines of Health Care. State of the World's Mothers 2010 [Internet]. Connecticut: Save The Children; 2010 May [cited 2019 Feb 16]. [Table], 2010 Mother's Index Rankings; p. 36. Available from: https://www.savethechildren.org/content/ dam/usa/reports/advocacy/sowm/sowm-2010 .pdf?vanityurl=publications/state-of-the-worlds -mothers-report

3. World Bank [Internet]. New York: World Bank; c2019. Datos. Prevalencia de VIH (\% de la población entre 15 y 24 años de edad). Todos los países y economías; [updated 2019 Jan; cited 2019 Feb 16]. Available from: https://datos.banco mundial.org/indicador/sh.dyn.aids.zs. Spanish.

4. Santana Espinosa MC, Esquivel Lauzurique M, Herrera Alcázar VR, Castro Pacheco BL, Machado Lubián MC, Cintra Cala D, et al. Atención a la salud materno-infantil en Cuba: logros y desafíos. Rev Panam Salud Pública [Internet]. 2018 [cited 2019 Feb 16];42:22-30. Available from: https://scielosp.org/pdf/rpsp/2018 .v42/e27/. Spanish.

5. Miller LJ, Lu W. These Are the Worlds Healthiest Nations. New York: Bloomberg [Internet]. 2019 Feb 24 [cited 2019 Mar 2]; Economics. Available from: https://www.bloomberg.com/news/ articles/2019-02-24/spain-tops-italy-as-world -s-healthiest-nation-while-u-s-slips

6. Datosmacro.com [Internet]. Datosmacro.com; c2019. Expansión. Cuba - Esperanza de vida al nacer; [cited 2019 Feb 16]. Available from: https://datosmacro.expansion.com/demografia/ esperanza-vida/cuba?anio=1960. Spanish.

7. Castro Pacheco BL, Cuéllar Álvarez R, IbargolIen Negrín L, Esquivel Lauzurique M, Machado Lubián MC, Martínez Corredera V. Cuban experience in child health care. 1959-2006 [Internet]. Havana: Editora Política; 2010 [cited 2019 Mar 2]. p. 9. Available from: https://ipa-world.org/ uploadedbyfck/Report $\% 20$ on $\% 20$ Child $\% 20$ Health\%20in\%20Cuba\%20by\%20Jose \%20 Martines_EXPERIENCIA\%20CUBANA\% 20 PARA\%20EDITORA\%20POLITICA\%20(EN GLISH\%20VERSION).pdf.

8. Keck CW, Reed GA. The curious case of Cuba. Am J Pub Health. 2012 Aug;102(8):e13-22.

9. Drain PK, Barry M. Fifty years of U.S. embargo: Cuba's health outcomes and lessons. Science. 2010 Apr 30;328(5978):572-3.

10. American Association for World Health. The Impact of the U.S. Embargo on Health \& Nutrition in Cuba [Internet]. Washington, D.C.: American As- sociation for World Health; 1997 Mar [cited 2019 Feb 16]. 322 p. Available from: https://medicc.org/ ns/documents/The_impact_of_the_U.S._Embar go_on_Health_\&_Nutrition_in_Cuba.pdf 1997

11. GAPMINDER [Internet]. Stockholm: GAPMIND ER; c2019. Updated GAPMINDER World Poster; [cited 2019 Feb 16]. Available from: https://www .gapminderdev.org/tag/chart

12. Morris E. Unexpected Cuba. New Left Rev. 2014 Jul-Aug;88:5-45.

13. Rojo Pérez N, Valenti Pérez C, Martínez Trujillo $\mathrm{N}$, Morales Suárez I, Martínez Torres E, Fleitas Estévez I, et al. Ciencia e innovación tecnológica en la salud en Cuba: resultados en problemas seleccionados. Rev Panam Salud Pública [Internet]. 2018 [cited 2019 Feb16];42:98-108. Available from: https://www.scielosp.org/pdf/ rpsp/2018.v42/e32/es. Spanish.

14. Constitución de la Organización Mundial de la Salud. Documentos Básicos. Supl 45a Edición [Internet]; Geneva: World Health Organization 2006 [cited 2019 Feb 16]. 20 p. Available from: https://www.who.int/governance/eb/who_consti tution_sp.pdf. Spanish.

15. Boorse C. A Rebuttal on Health. In: Humber J. and Almeder R, editors. What is Disease? Biomedical Ethics Reviews. New Jersey: Humana Press; 1997. p. 1-134.

16. Nordenfelt LY. Action, Ability and Health: Essays in the Philosophy of Action and Welfare. Dordrecht: Springer Netherlands; 2000. $173 \mathrm{p}$

17. Lage Dávila $C$, Álvarez Pérez AG, Luis Gonzálvez IP, Maldonado Cantillo G, Bonet Gorbea MH. Los determinantes sociales de la salud. Actualización. InfoHEM [Internet]. 2015 Jan-Mar [cited 2019 Feb 16];13(1):57-75 Available from: https://www.researchgate.net/ publication/305816699_Los_Determinantes_So ciales_de la_Salud_Actualizacion. Spanish.

18. World Health Organization. World Conference on Social Determinants of Health. Rio Political Declaration on Social Determinants of Health. Rio de Janeiro, Brazil, 21 October 2011 [Internet]. Geneva: World Health Organization; 2011 [cited 2019 Feb 16]. 7 p. Available from: https:// www.who.int/sdhconference/declaration/Rio_po litical_declaration.pdf?ua=1

19. Álvarez AG, García A, Bonet MH. Pautas conceptuales y metodológicas para explicar los determinantes de los niveles de salud en Cuba Rev Cubana Salud Pública [Internet]. 2007 [cited 2019 Feb 16]. Available from: http://scielo.sld.cu/ pdf/rcsp/v33n2/spu13207.pdf. Spanish.

20. De la Torre Montejo E, López Pardo C, Márquez M, Gutiérrez Muñiz J, Rojas Ochoa F, editors Salud Para Todos Sí Es Posible. Havana: MercieGroup - ENPSES, CUJAE; 2005. Spanish.

21. Zajacova A, Lawrence EM. The relationship between education and health: reducing disparities through a contextual approach. Annu Rev Public
Health . 2018 April 01;39:273-89. DOI:10.1146/ annurev-publhealth-031816-044628.

22. Lage A. La Osadía de la Ciencia. Havana: Editorial Academia; 2018. Spanish.

23. Álvarez JY, De la Osa JA. Apuntes sobre Salud y Ciencia en Cuba. Madrid: Editorial Sangova, S.A.; 2002. Spanish.

24. Pruna Goodgall PM, Gálvez Sandoval O, Fernández Prieto L, Valero González M, Beldarraín Chaple E, Ramos Guadalupe LE, et al. Historia de la ciencia y la tecnología en Cuba. Havana: Editorial Científico-Técnica; 2006. Spanish.

25. Jordán JR. Desarrollo Humano en Cuba. Havana Editora Científico Técnica; 1979. p. 150. Spanish

26. Kohler G, Milstein C. Continuous cultures of fused cells secreting antibodies of predefined specificity. Nature. 1975 Aug 7; 256:495-7.

27. Ministry of Public Health (CU). Registro Nacional de Cáncer [Internet]. Havana: Ministry of Public Health (CU); 2019 [cited 2019 Feb 16]. Available from: http://www.rnc.sld.cu/. Spanish.

28. Ministry of Public Health (CU). Programa integral para el control del cáncer en Cuba. Estrategia nacional para el control del cáncer [Internet] Havana: Editorial Ciencias Médicas; 2012 [cited 2019 Feb 16]. 25 p. Available from: https://www iccp-portal.org/system/files/plans/CUB_B5 CUB Estrategia cancer.pdf. Spanish.

29. Urra P. Cuba \& ICTs: real crisis leads to virtual innovation. MEDICC Rev. 2008 Winter;10(1):52.

30. World Health Organization. Cuban experience with local production of medicines, technology transfer and improving access to health [Internet] Geneva: World Health Organization; 2015 [cited 2019 Feb 16]. Available from: http://www.who.int/ phi/publications/cuban_experience_local_prod medstech transfer/en

31. Grupo de las Industrias Biotecnológica y Farmacéutica de Cuba. BioCubaFarma [Internet]. Havana: BioCubaFarma; c2019 [cited 2019 Feb 16]. Available from: https://www.biocubafarma .cu. Spanish.

32. Reed G. Thirty years of technology at work for health: Niurka Carlos, Director, Immunoassay Center, Havana. MEDICC Rev. 2017 Oct:19(4):6-8

33. Fulop T, Larbi A, Dupuis G, Le Page A, Frost EH Cohen AA, et al. Immunosenescence and InflammAging as two sides of the same coin: Friends or Foes? Front Immunol [Internet]. 2018 Jan 107 [cited 2019 Feb 16];8:1960. Available from: https:// www.ncbi.nlm.nih.gov/pmc/articles/PMC5767595/

34. Saavedra D, García B, Lage A. T-Cell subpopulations in healthy elderly and lung cancer patients: insights from Cuban studies. Front Immunol 2017 Feb 14;8:146.

35. Bacallao J, Alerm A, Ferrer M. Paradigma del curso de la vida. Sus implicaciones en la clínica, la epidemiología y la salud pública. Havana: ECIMED; 2016. Spanish. 
36. US Drug \& Food Administration [Internet]. Washington, D.C.: US Drug \& Food Administration; c2019. Drugs Databases. Drugs@FDA: FDAApproved Drug Products. Insulin recombinant human; [cited 2019 Feb 16]. Available from: https:// www.accessdata.fda.gov/scripts/cder/daf/index .cfm?event $=$ overview. process $\& A$ pp INo $=018780$

37. Evaluate Pharma World Preview 2016. Outlook to 2022 [Internet]. London: Evaluate Pharma; 2016 Sep [cited 2019 Mar 2]. 49 p. Available from: https://info.evaluategroup.com/rs/607-YGS -364/images/wp16.pdf

38. Couzin-Frankel J. Breakthrough of the year 2013: cancer immunotherapy. Science. 2013 Dec 20;342(6165):1432-3.

39. Booth CM, Cescon DW,Wang L, Tannock IF, Krzyzanowska MK. Evolution of the randomized clinical trials in oncology over three decades. J Clin Oncol. 2008 Nov 20;26(33):5458-64.

40. Lage A. Global pharmaceutical development and access: critical issues of ethics and equity. MEDICC Rev. 2011 Jul;13(3):16-22.
41. Blanco-García E, Ledón N, Lage-Dávila A. Rising cancer drug prices: what can low- and middleincome countries do? MEDICC Rev. 2018 Oct;20(4):35-9.

42. The National Institute for Health and Care Excellence (NICE) [Internet]. London: National Institute for Health Care Excellence (NICE); c2019 [cited 2019 Feb 16]. Available from: https://www .nice.org.uk

43. Wolfe RM, Sharpe LK. Anti-vaccinationists past and present. BMJ. 2002 Aug 24;325(7361):430-2

44. World Health Organization [Internet]. Geneva: World Health Organization; c2019. Diseases. Emergencies preparedness, response. Smallpox; [cited 2019 Feb 16]. Available from: https:// www.who.int/csr/disease/smallpox/en/

45. World Health Organization. Polio. Eradication [Internet]. Geneva: World Health Organization; 2018 Nov 26 [cited 2019 Feb 16]. 7 p. Available from: http://polioeradication.org/wp-content/up loads/2016/07/B144_9-en.pdf

\section{THE AUTHOR}

Agustín Lage-Dávila (lage@cim.sld.cu), physician specializing in biochemistry with a doctorate in medical sciences. Senior researcher and full professor, Molecular Immunology Center. Scientific advisor to the President, BioCubaFarma, Havana, Cuba.

Submitted: January 14, 2019

Approved for publication: June 16, 2019 Disclosures: None

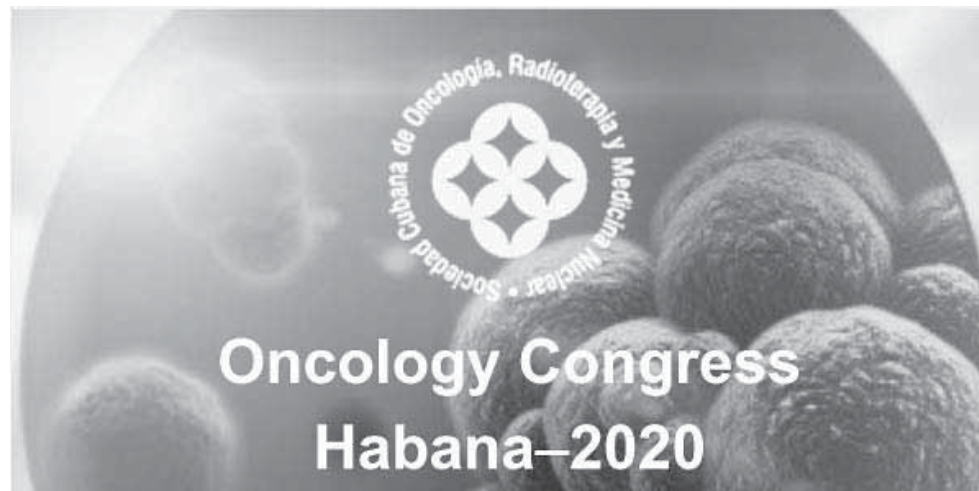

March 25-27, 2020 Havana's International Convention Center

\section{Main Topics}

- Controversies in cancer patient management

- Personalized medicine

- Pre-clinical/clinical evaluation of new drugs

- Diagnosis and control of tumors in children and adults

- Biomarkers' role in individualized treatment

- Immunotherapy

- Epidemiology and cancer registries

- Cancer prevention and control

- Palliative care

- Advances in nuclear medicine

- Medical education in oncology

- Psycho-oncology

\section{Languages: Spanish, English}

Organizer: Cuban Society of Oncology, Radiology and Nuclear Medicine
Contact: Dr Eva Salomón Zaldívar
Kaineva@infomed.sld.cu
www.oncologiahabana2020.com/en/invitation 